DOI: 10.20472/IAC.2018.044.049

\author{
EDWIN THERON \\ Stellenbosch University, South Africa
}

\title{
MANAGING COMMITMENT IN THE PERSONAL CARE SERVICE INDUSTRY: THE SPECIAL CASE OF HAIRDRESSING SERVICES.
}

\begin{abstract}
:
Since its inception, the concept of customer commitment has been extensively researched, especially in the field of relationship marketing. It is therefore not surprising to find that the concept of commitment has been applied to various industries, both on an academic and practical level. However, the same cannot be said about the personal care service industry, which refers to industries that are characterised by high levels of customer interaction during the service delivery process. These industries include the hairdressing, legal services and medical services industries. This study focuses on the management of customer commitment from a personal care service perspective. The specific context of the study is the hairdressing industry. The study applies Meyer and Allen's well-documented three-component model of commitment, and investigates the management of affective, calculative and normative commitment in the hairdressing industry. $\mathrm{A}$ quantitative approach was used to analyse the perceptions of 270 Generation $Y$ respondents. Generation Y, also known as the millennials, refers to people who were born in the 1980s and 1990s. The data were analysed in SPSS version 25, and a regression analysis was used to assess the statistical significance of the hypothesised relationships. The results of the study indicate that satisfaction, social bonds, attractiveness of alternatives, relationship benefits and communication are significant antecedents of customer commitment in the hairdressing industry. The primary contribution of the study lies in the fact that it provides both theoretical insights and practical recommendations on how customer commitment in this relatively under-researched context should be managed.
\end{abstract}

\section{Keywords:}

Customer commitment

Personal care service industry

Hairdressing

JEL Classification: M00, M31 


\section{Introduction}

There has been a growing interest in the application of relationship marketing in a service context (Gummerus, Von Koskull \& Kowalkowski, 2017), especially because of the benefits that both service providers and customers may obtain from using relationship marketing principles (Hennig-Thurau, Gwinner \& Gremler, 2002). Although the literature has identified several dimensions through which long-term marketing relationships can be managed, commitment is often viewed as an important dimension of such a relationship (Parsa \& Sadeghi, 2015).

Although commitment has been described as a unidimensional construct (Bügel, Verhoef \& Buunk, 2011; Hennig-Thurau et al., 2002), Meyer and Allen (1991) argue that commitment consists of three components, namely affective, calculative and normative commitment, which is referred to as the three-component model of commitment. Furthermore, the marketing literature distinguishes between commitment towards personal services (such as hairdressing) and non-personal service providers (such as financial services) (Jones, Fox, Taylor \& Fabrigar, 2010). However, research on the application of the three-component model of commitment to the personal care service industry, particularly hairdressing, appears to be limited. The aim of this study was therefore to analyse the management of commitment, and specifically its three components, in the hairdressing industry.

\section{Commitment}

Although different views exist on the exact nature and meaning of the term commitment, the definition of commitment as suggested by Moorman, Zaltman and Deshpande (1992) is acknowledged as one of the most comprehensive definitions available. According to this definition, commitment refers to "an enduring desire to maintain a valued relationship" (Moorman et al.,1992: 316).

The important role of commitment in a long-term marketing relationship is welldocumented (Zhang, Watson, Palmatier, \& Dant, 2016; Bansal, Irving \& Taylor, 2004; Fullerton, 2003). Nusair, Parsa and Cobanoglu (2011) argue that customer commitment is a key psychological force that links customers to relationships. From a services marketing perspective, Curth, Uhrich and Benkenstein (2014) are of the opinion that commitment is an important determinant of a customer's relationship with a service provider, whereas Bansal et al. (2004) believe that commitment can be a useful construct when studying the relationship between customers and their service providers.

Despite the notion that commitment should be viewed as a unidimensional construct (Klein, Cooper, Molloy \& Swanson, 2014), a number of studies posit that commitment consists of three distinct components, namely an affective, a calculative and a normative component (Jones et al., 2010; Cater \& Zabkar, 2009; Meyer \& Allen, 1991). However, 
it is important to mention that the multidimensional nature of commitment has recently received renewed interest (Tsunogaya, Sugahara \& Chand, 2017).

Affective commitment can be defined as "the degree to which a customer is psychologically bonded to the service organization on the basis of how favourable the consumer feels about the organization" (Jones et al., 2010:18). Affective commitment refers to a customer's desire to remain in a relationship and is focused on a positive emotional attachment or bond to the service organisation (Gruen, Summers \& Acito, 2000; Jones et al., 2010). It thus denotes a component of a strong feeling or emotion.

The second component, namely calculative commitment, refers to "the degree to which a customer is psychologically bonded to the organization on the basis of the perceived costs associated with terminating the relationship" (Jones et al., 2010:18). According to Gruen et al. (2000), these perceived costs can be economic-, social- or status-related. This particular dimension of commitment reflects a customer's perception of sacrifice associated with ending a relationship with the service provider and includes activities such as weighing up the switching costs and evaluating alternatives (Jones et al., 2010).

Normative commitment on the other hand, refers to "the degree to which a customer is psychologically bonded to the organization on the basis of his or her sense of obligation to the organization" (Jones et al., 2010:18). According to Bansal et al. (2004), this type of commitment is based on obligation, as it usually develops from social pressure to perform in a certain manner and/or conform to certain standards or behaviour.

\subsection{The relationship between affective, calculative and normative commitment}

Affective, calculative and normative commitment should be viewed as separate, but related constructs in services relationships (Jones et al., 2010; Bansal et al., 2004). Disagreement, however, exists on the distinctiveness of these components, mainly because of the possible overlapping of these three components. Cohen (2007) argues that an overlap exist between affective and normative commitment. This finding is in agreement to an earlier argument that especially affective and normative commitment are often correlated (Meyer, Stanley, Herscovitch \& Topolnytsky, 2002). In contrast, Jones et al. (2010) note that sufficient evidence exists that these three components are distinct concepts. Despite this argument, Jones et al. (2010) warn that the three components should not be viewed in isolation, but that the best results are obtained when they are applied in combination with each other.

\subsection{Antecedents of commitment}

Studies regarding the antecedents of commitment are context-specific, which complicates the process of deriving antecedents that are specifically applicable to the personal care service industry. Therefore, where relevant literature was not available, this study had to rely on the general customer commitment theory. Although various 
antecedents of commitment have been found in the literature, this study focuses on those antecedents that fit the description of the personal care service industry. The study therefore identified the following six antecedents of customer commitment: trust, satisfaction, social bonds, attractiveness of alternatives, relationship benefits and communication. They will each be discussed in the sections that follow.

\subsubsection{Trust}

Moorman et al. (1992:315) define trust as "a willingness to rely on an exchange partner in whom one has confidence". Based on the marketing literature, it is clear that trust is not only an important dimension of the marketing literature, but that it is also one of the most frequently cited antecedents of commitment (Bricci, Fragata \& Antunes, 2016; Cater \& Zabkar, 2009; Wetzels et al., 1998). Fullerton (2011), points out that trust is an essential component to the formation of commitment; in fact, commitment cannot exist without the prevalence of trust. In relation to the personal care service industry, Fullerton (2011) found that trust has a significant positive effect on both affective and normative commitment. Also, Bansal et al. (2004) noticed that the stronger a customer's trust in a service provider, the stronger the customer's affective commitment will be towards that service provider. Similarly, De Ruyter, Moorman and Lemmink (2001) argue that trust leads to high levels of affective commitment.

Based on the literature review, the following hypotheses were developed:

$\mathrm{H} 1 \mathrm{a}$ There is a positive relationship between trust and affective commitment $\mathrm{H} 1$ b There is a positive relationship between trust and calculative commitment $\mathrm{H} 1 \mathrm{c}$ There is a positive relationship between trust and normative commitment

\subsubsection{Satisfaction}

As in the case with trust, satisfaction is also a key construct in the management of commitment in a service industry context (Wetzels et al., 1998). Satisfaction, which is defined as "the degree to which a business's product or service performance matches up to the expectation of the customer" (Van Vuuren, Roberts-Lombard \& Van Tonder, 2012:84), implies that satisfaction is a continuous process of comparing expectations and perceived performance. Hocutt (1998) reported a positive relationship between customers' satisfaction with a service provider and their commitment to the relationship. In addition, Sohaib, Rehman and Akram (2016) claim that satisfaction positively influences and enhances customers' commitment towards suppliers. Similarly, Lee, Huang and Hsu (2007) state that high levels of satisfaction provide customers with repeated positive reinforcement that consequently leads to commitment-inducing bonds.

Jones et al. (2010) assert that satisfaction is a particularly strong predictor of affective commitment. Nusair et al. (2011) found that satisfaction has a positive relationship with 
affective commitment, whilst Wetzels et al. (1998) established that satisfaction is positively related to both affective and calculative commitment. These findings were confirmed by Shemwell, Yavas and Bilgin (1998). In terms of normative commitment, $\mathrm{Fu}$, Bolander and Jones (2009) confirmed a positive relationship between satisfaction and normative commitment.

Given the support that was found for satisfaction in the literature, the following hypotheses were formulated:

$\mathrm{H} 2 \mathrm{a}$ There is a positive relationship between satisfaction and affective commitment

$\mathrm{H} 2 \mathrm{~b} \quad$ There is a positive relationship between satisfaction and calculative commitment

$\mathrm{H} 2 \mathrm{c}$ There is a positive relationship between satisfaction and normative commitment

\subsubsection{Social bonds}

Considering the unique nature of the personal care service industry, it can be expected that social interaction plays an important role when managing commitment in this industry. Research indicates that friendships with customer contact personnel affect customer commitment; it therefore came as no surprise that Hocutt (1998) established a positive relationship between social bonds and customer commitment. Social bonding is defined by Paulssen and Roulet (2017:1013) as "a feeling of friendship and liking shared by the buyer and seller". Wang (2014) describes social bonds as positive interpersonal relationships that are important for building business relationships; and that social bonds also have a strong element of friendship. This argument was confirmed by Ponder, Holloway and Hansen (2016), namely that creating social bonds between customers ultimately results in increased customer commitment.

Wang (2014) found that social bonds (as the independent variable) display a positive relationship with affective and normative commitment respectively. Hocutt (1998) infers that a customer will stay committed to a personal care service provider because of the close, personal relationship that has been formed over the years. Furthermore, Chai, Deans and Biggeman (2012), established that friendships (often used interchangeably with social bonding in the literature), between customers and contact personnel positively affect customer commitment.

In light of the aforementioned discussion, the following hypotheses were stated:

$\mathrm{H} 3_{\mathrm{a}}$ There is a positive relationship between social bonds and affective commitment

$\mathrm{H} 3 \mathrm{~b}$ There is a positive relationship between social bonds and calculative commitment

$\mathrm{H} 3 \mathrm{c}$ There is a positive relationship between social bonds and normative commitment 


\subsubsection{Attractiveness of alternatives}

Sharma and Patterson (2000:475) define attractiveness of alternatives as "the client's estimate of the likely satisfaction available in an alternative relationship". Owing to the competitiveness of the service industry, the influence of attractiveness of alternatives is often analysed as an antecedent of commitment (Nusair et al., 2011; Bügel, Buunk \& Verhoef, 2010; Theron, Terblanche \& Boshoff, 2008). Theron et al. (2008) established that attractiveness of alternatives has a positive relationship with relationship commitment. This positive relationship was confirmed by Yim, Chan and Hung (2007) in a personal service context, and more specifically in the domain of hairdressing.

It appears that research on the effect of attractiveness of alternatives on the three different components of commitment is limited. Although Bansal et al. (2004) and Nusair et al. (2011) investigated the relationship between attractiveness of alternatives and calculative commitment, none of the two studies succeeded in establishing a relationship. However, given the competitive nature of the hairdressing industry, it was decided to include attractiveness of alternatives in this study.

Therefore, the following hypotheses were put forward:

$\mathrm{H} 4 \mathrm{a}$ There is a positive relationship between attractiveness of alternatives and affective commitment

$\mathrm{H} 4 \mathrm{~b}$ There is a positive relationship between attractiveness of alternatives and calculative commitment

$\mathrm{H} 4 \mathrm{c}$ There is a positive relationship between attractiveness of alternatives and normative commitment

\subsubsection{Relationship benefits}

Theron and Terblanche (2010) suggest that relationship benefits is one of the most important dimensions in establishing and managing long-term marketing relationships. The construct relationship benefits can be described as "benefits customers are likely to receive because of having cultivated a long-term relationship with a service provider" (Hennig-Thurau et al. (2002). According to Kim and Ok (2009), relationship benefits consist of three important elements, namely social benefits, confidence benefits and special treatment benefits. However, the marketing literature differs on the importance of these three elements when commitment is managed. For example, Hennig-Thurau et al. (2002) discovered that only social and special treatment benefits influenced commitment, whilst Dagger, David and $\mathrm{Ng}$ (2011) argue that all three these elements are required when commitment is managed (i.e. including confidence benefits). In general, relationship benefits, studied as a unidimensional construct, was found to be an antecedent of commitment (Dagger et al., 2011; Theron et al., 2008; Sweeney \& Webb, 2007). 
The correlation between relationship benefits and the components of commitment is under-researched. However, Kim and Ok (2009) found a significant positive relationship between all three elements of relationship benefits (social, confidence and special treatment benefits) and affective commitment. In addition, Beatty, Reynolds, Noble and Harrison (2012) discovered that relationship benefits have a positive association with affective commitment.

Based on the literature review, the following three hypotheses were formulated:

$\mathrm{H} 5 \mathrm{a}$ There is a positive relationship between relationship benefits and affective commitment

$\mathrm{H} 5 \mathrm{~b}$ There is a positive relationship between relationship benefits and calculative commitment

$\mathrm{H} 5 \mathrm{c}$ There is a positive relationship between relationship benefits and normative commitment

\subsubsection{Communication}

The importance of communication in any marketing relationship is well-established in the literature. Standifer, Evans and Dong (2010) define communication as the formal and informal sharing of information between parties, whereas Andersen (2001:168) views communication in a marketing context as "the human act of transferring a message to others and making it understood in a meaningful way".

Once again, limited research exists regarding the relationship between communication and commitment. Cater (2007) asserts that communication is one of the factors that influence the development of relationship commitment. This notion is supplementary to an earlier view of Andersen (2001) that there are indicators that communication has a direct impact on commitment in relationship marketing. Theron et al. (2008) found a positive relationship between communication and commitment. In terms of the components of commitment, Cater (2006) found a positive relationship between communication and affective commitment. This finding was confirmed by Ter Hoeven and Verhoeven (2013). In a similar vein, Wu, Chiag, Wu and Tu (2004) discovered that communication has a positive effect on all three components of commitment.

The literature review resulted in the following hypotheses:

$\mathrm{H} 6 \mathrm{a}$ There is a positive relationship between communication and affective commitment

H6b There is a positive relationship between communication and calculative commitment

$\mathrm{H} 6 \mathrm{c}$ There is a positive relationship between communication and normative commitment 
The hypothesised relationships are depicted in Figure 1:

\section{Figure 1: Hypothesised relationships}

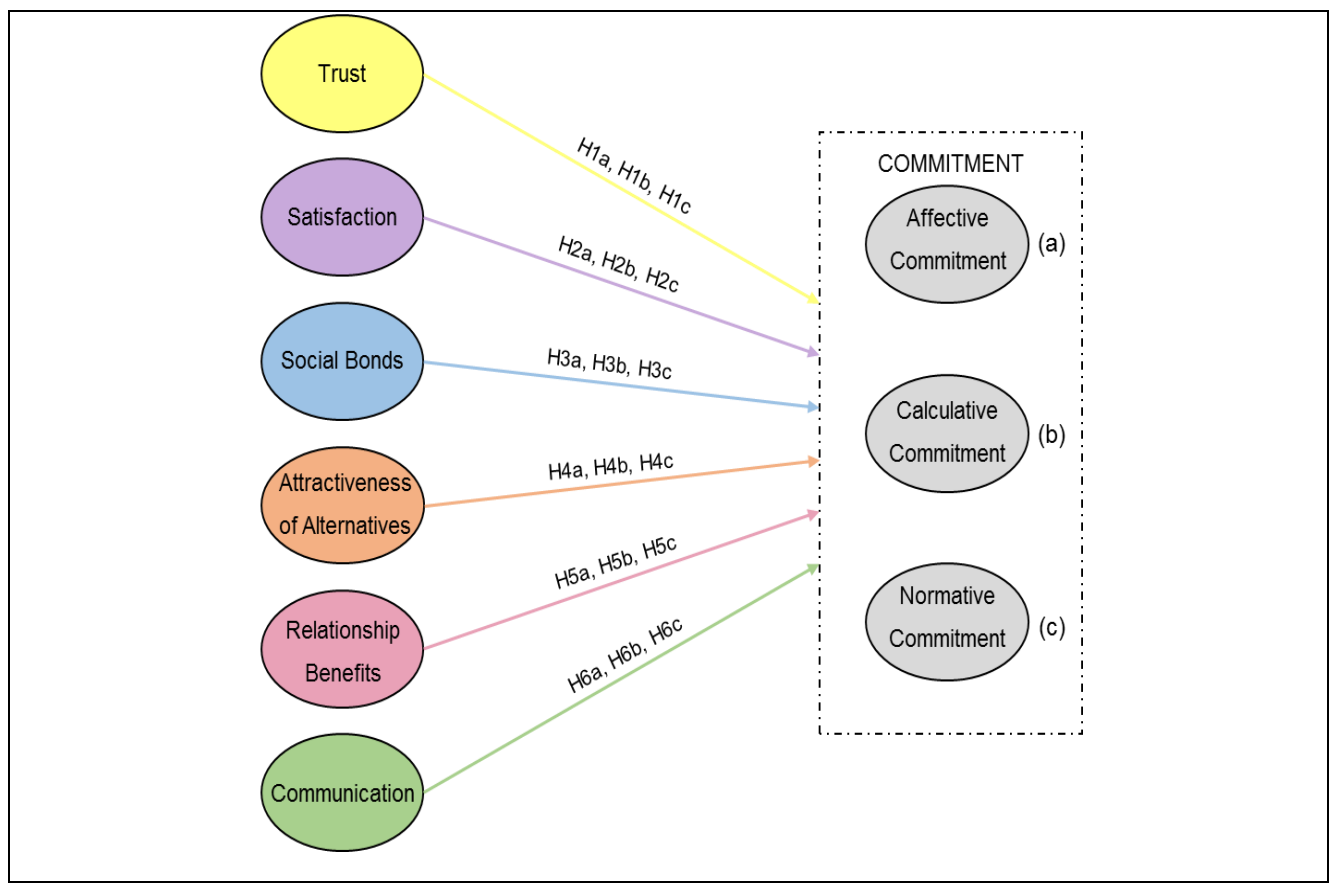

\section{Context of the study}

This study was conducted in the personal care service industry, which can be described as a service where the customer is most likely to interact with the same employee during each visit or service encounter (Jones et al., 2010). Personal services can be characterised by high levels of service-customer contact, employee contact, people orientation and customisation (Watson, 2012). In addition, personal services involve uncertainty about the outcome of the service, because of the lack of control over the actions of service workers (Bove \& Robertson, 2005). Furthermore, personal services have high contact and interpersonal levels, where personalisation often occurs (Jones et al., 2010). Given these characteristics, examples of personal services include medical practitioners, attorneys and hairdressers.

The hairdressing industry was selected as specific context for this study for two main reasons. First, because of the unique nature of the industry and the fact that it is an under-researched topic, and secondly, because of the opportunity that exists for a customer to commit themselves to a specific hairdresser. From a global perspective, it is estimated that the hair care industry will be worth US $\$ 87.73$ billion in 2018. This amount can increase to US $\$ 102.28$ by 2024 (Global hair care market size 2012-2024, 2017). Unfortunately, detailed statistics regarding the South African hairdressing industry is not only inadequate, but also dated. However, it has been reported that the South African hair care industry is growing at a rapid pace, with a growth rate of 38 per cent during the period 2010 to 2015 (Hair care in South Africa, 2017). The fastest 
growing segment in this industry is the black hair care industry, of which the value is estimated at R9.7 billion a year (By numbers: How big is the hair industry?, 2017). However, these figures should be deemed with caution, since it refers to the entire hair care industry, which is not necessarily the same than the hairdressing industry. For the purpose of this study, the hairdressing industry refers to both the hair care industry (the tangible part of the actual hair products being used), and the service component (the intangible part of the industry).

\section{Research method}

Measurement instrument: Data were collected by means of a non-interactive, selfadministered questionnaire. The three dependent variables and the independent variables were measured according to scales sourced from the literature. Only scales of which the reliability were previously established, were included. The items were mainly sourced from Curth et al. (2014), Jones et al. (2010), Cater and Zabkar (2009) and Bansal et al. (2004). Five items were used to measure each of the variables, resulting in a measurement instrument consisting of 45 items. An additional six items measured the demographics of the respondents. Although some of the items had to be adapted slightly to reflect the specific context of the study, it was done in such a manner that the original meaning of the items was not affected.

Sampling: This study's target population was anyone who made use of a hairdresser. Since no sampling frame was available, a non-probability sampling technique was applied. Ultimately, the sample consisted of Generation Y customers from a leading and culturally diverse South African university.

Data analysis: Respondents' demographic profiles were described in terms of their gender, age and visiting patterns to hairdressers. The inferential analyses included an assessment of the reliability of the measurement instrument (by means of Cronbach alpha), an exploratory factor analysis (EFA) and multiple regression. All analyses were conducted with SPSS (version 24), using a 95 per cent confidence interval.

\section{Empirical results}

\subsection{Realised sample and demographic profile}

The measurement instrument commenced with a qualifying question of whether the respondents made use of the services of a hairdresser or not. Based on a significant number of respondents answering "no" to the qualifying question, only 270 of the original 307 returned questionnaires could be used.

The vast majority of the realised sample, namely 98.52 per cent consisted of $Y$ generation individuals between the ages of 18 and 24 years. From a gender perspective, 58.15 per cent of the respondents were female and 41.48 per cent were 
male. Two respondents did not indicate their gender. The frequency of visits to a hairdresser was also analysed, with the majority of respondents $(70.0 \%)$ indicating that they visited a hairdresser every two months or less. Only 30 respondents $(11.11 \%)$ visited their hairdressers once a month. These results should be viewed against the background of South Africans who, on average, visit a hairdresser every four to six weeks (Statista, 2015). In terms of variation in the use of specific hairdressers, 84.44 per cent of the respondents indicated that they only used one specific hairdresser. It can therefore be argued that the majority of respondents were interested in building a longer-term relationship with their specific hairdressers. Furthermore, 58.41 per cent of female respondents compared to 40.71 per cent of their male counterparts indicated that the duration of the relationship with their current hairdresser was between one and three years.

\subsection{Results of the pre-test}

To establish the reliability of the items used to measure the six independent variables and the three dependent variables, a pre-test was conducted. The results of the pretest revealed Cronbach alpha values for eight of the nine variables of between 0.787 and 0.898 , indicating sufficient reliability. The only exception was attractiveness of alternatives, where the reliability score was a mere 0.472 . Further inspection of this variable revealed that by removing one of the items measuring attractiveness of alternatives, it was possible to increase the Cronbach alpha value to 0.836 . In this way, the reliability of all nine the variables were ensured.

\subsection{Results of the main study}

Once data collection of the main study was completed, an EFA was performed. Direct Oblimin was selected as rotation method, and Principal axis factoring was the extraction method. The results of the EFA are presented in Table 1. 


\section{Table 1: Results of the EFA}

\begin{tabular}{|c|c|c|c|c|c|}
\hline \multicolumn{6}{|c|}{ PATTERN MATRIX } \\
\hline \multirow{2}{*}{ Item } & \multicolumn{5}{|c|}{ Factor } \\
\hline & 1 & 2 & 3 & 4 & 5 \\
\hline CMU1 & .650 & & & & \\
\hline soc1 & .627 & & & & \\
\hline soc3 & .603 & & & & \\
\hline soc2 & .513 & & & & \\
\hline soc4 & .508 & & & & \\
\hline SOC5 & .417 & & & & \\
\hline ATT2 & & .816 & & & \\
\hline ATT4 & & .804 & & & \\
\hline АTT3 & & .799 & & & \\
\hline ATT1 & & .574 & & & \\
\hline RLB4 & & & -.929 & & \\
\hline RLB5 & & & -.742 & & \\
\hline RLB1 & & & -.678 & & \\
\hline RLB3 & & & -.537 & & \\
\hline CMU4 & & & & -.788 & \\
\hline CMU2 & & & & -.787 & \\
\hline CMU5 & & & & -.653 & \\
\hline CMU3 & & & & -.524 & \\
\hline TRU3 & & & & & .699 \\
\hline SAT2 & & & & & .687 \\
\hline TRU1 & & & & & .687 \\
\hline SAT1 & & & & & .663 \\
\hline SAT4 & & & & & .585 \\
\hline SAT3 & & & & & .487 \\
\hline SAT5 & & & & & .473 \\
\hline
\end{tabular}

The EFA revealed five factors, and not six as anticipated. A clear pattern emerged for both attractiveness of alternatives, relationship benefits and communication; these three labels were therefore retained. Social bonds consisted of all five the original social bond items, as well as one item from the communication factor. In the case of satisfaction, the new factor consisted of four of the original satisfaction items, together with one trust item. Since both social bonds and satisfaction primarily consisted of the original items, it was decided to retain the original labels. Furthermore, all five original labels were retained, and no renumbering of the hypotheses was thus required. The only exception was the removal of hypotheses $\mathrm{H} 1 \mathrm{a}, \mathrm{H} 1 \mathrm{~b}$ and $\mathrm{H} 1 \mathrm{c}$, because the EFA revealed that trust was no longer a variable in this study. The Cronbach alpha scores of the five newly computed variables ranged between 0.835 and 0.879 , whilst the reliability scores for 
the three dependent variables, ranged between 0.811 and 0.902 . It can therefore be concluded that all measures used in the remainder of the study, demonstrated sufficient levels of reliability.

A separate regression analysis was performed on each of the three dependent variables. The results of the three regression analyses are shown in Table 2.

Table 2: Results of the regression analyses

\begin{tabular}{|c|c|c|c|c|c|c|c|}
\hline \multirow{2}{*}{$\begin{array}{l}\text { Independent } \\
\text { variables }\end{array}$} & \multicolumn{2}{|c|}{ Unstand. coeff. } & \multirow{2}{*}{$\begin{array}{c}\begin{array}{c}\text { Stand. } \\
\text { coeff. }\end{array} \\
\text { Beta }\end{array}$} & \multirow[b]{2}{*}{$\mathrm{t}$} & \multirow[b]{2}{*}{ Sig. } & \multicolumn{2}{|c|}{ Collinearity statistics } \\
\hline & B & Std. error & & & & Tol. & VIF \\
\hline \multicolumn{8}{|c|}{ Regression 1: Affective commitment } \\
\hline Satisfaction & 0.411 & 0.071 & 0.294 & 5.777 & 0.000 & 0.470 & 2.129 \\
\hline Social bonds & 0.368 & 0.060 & 0.322 & 6.144 & 0.000 & 0.445 & 2.248 \\
\hline $\begin{array}{l}\text { Attractiveness of } \\
\text { alternatives }\end{array}$ & -0.031 & 0.047 & -0.027 & -0.661 & 0.509 & 0.717 & 1.394 \\
\hline $\begin{array}{l}\text { Relationship } \\
\text { benefits }\end{array}$ & 0.161 & 0.039 & 0.177 & 4.095 & 0.000 & 0.652 & 1.534 \\
\hline Communication & 0.248 & 0.052 & 0.231 & 4.809 & 0.000 & 0.527 & 1.897 \\
\hline \multicolumn{8}{|l|}{$R^{2}=0.6813$} \\
\hline \multicolumn{8}{|c|}{ Regression 2: Calculative commitment } \\
\hline Satisfaction & 0.304 & 0.089 & 0.240 & 3.403 & 0.001 & 0.470 & 2.129 \\
\hline Social bonds & -0.080 & 0.075 & -0.076 & -1.056 & 0.292 & 0.445 & 2.248 \\
\hline $\begin{array}{l}\text { Attractiveness of } \\
\text { alternatives }\end{array}$ & -0.203 & 0.060 & -0.194 & -3.406 & 0.001 & 0.717 & 1.394 \\
\hline $\begin{array}{l}\text { Relationship } \\
\text { benefits }\end{array}$ & 0.265 & 0.049 & 0.321 & 5.372 & 0.000 & 0.652 & 1.534 \\
\hline Communication & 0.307 & 0.065 & 0.316 & 4.742 & 0.000 & 0.527 & 1.897 \\
\hline \multicolumn{8}{|l|}{$R^{2}=0.3909$} \\
\hline \multicolumn{8}{|c|}{ Regression 3: Normative commitment } \\
\hline Satisfaction & 0.402 & 0.106 & 0.266 & 3.800 & 0.000 & 0.470 & 2.129 \\
\hline Social bonds & 0.228 & 0.089 & 0.184 & 2.560 & 0.011 & 0.445 & 2.248 \\
\hline $\begin{array}{l}\text { Attractiveness of } \\
\text { alternatives }\end{array}$ & -0.218 & 0.071 & -0.175 & -3.090 & 0.002 & 0.717 & 1.394 \\
\hline $\begin{array}{l}\text { Relationship } \\
\text { benefits }\end{array}$ & 0.105 & 0.058 & 0.107 & 1.804 & 0.072 & 0.652 & 1.534 \\
\hline Communication & 0.308 & 0.077 & 0.265 & 4.017 & 0.000 & 0.527 & 1.897 \\
\hline
\end{tabular}

The first regression analysis (with affective commitment as dependent variable), found support for four of the five hypothesised relationships. Based on the significance levels and the $\beta$-values indicated in Table 2, support was therefore found for the positive effect of satisfaction, social bonds, relationship benefits and communication on affective commitment. In this way, hypotheses $\mathrm{H} 2 \mathrm{a}, \mathrm{H} 3_{\mathrm{a}}, \mathrm{H} 5_{\mathrm{a}}$ and $\mathrm{H} 6_{\mathrm{a}}$ were supported. $\mathrm{H} 4_{\mathrm{a}}$ (the hypothesised relationship between attractiveness of alternatives and affective commitment), was the only relationship that was not supported in the first regression 
analysis. Furthermore, multicollinearity among the independent variables did not appear to be an obstacle since all the VIF indices and tolerance levels were within the generally accepted margins. In terms of the $\mathrm{R}^{2}$ value of 0.6813 , almost 68 per cent of the variance in affective commitment was declared by the independent variables.

During the second regression analysis, calculative commitment was set as the dependent variable, with the same set of independent variables that was used in the first regression analysis. Support was found for satisfaction, attractiveness of alternatives, relationship benefits and communication as antecedents of calculative commitment. However, unlike the outcome of the first regression analysis, not all hypothesised relationships were found to be positively related to calculative commitment. Whilst satisfaction, relationship benefits and communication were indeed positively related to calculative commitment, a negative relationship was found between attractiveness of alternatives and calculative commitment. This finding implies that the more attractive alternatives become, the less the customer's calculative commitment towards their hairdresser will be. Support was therefore found for hypotheses $\mathrm{H} 2 \mathrm{~b}, \mathrm{H} 5 \mathrm{~b}$, $\mathrm{H} 6_{b}$ (positive relationships) and $\mathrm{H} 4_{b}$ (a negative relationship). Once again, multicollinearity among the independent variables was not a concern, as all tolerance values were higher than 0.1 , and VIF levels were lower than 10 . In terms of the variance in the dependent variable, as measured by the R2-value, the study managed to declare almost 40 per cent of the variance.

The third regression analysis focused on normative commitment as dependent variable. The results shown in Table 2 provide evidence for the support for four of the five hypothesised relationships. In this way, the study found support for hypotheses $\mathrm{H} 2 \mathrm{c}$, $\mathrm{H} 3_{\mathrm{c}}, \mathrm{H} 4_{\mathrm{c}}$ and $\mathrm{H} 6_{\mathrm{c}}$. However, in the case of $\mathrm{H} 4_{\mathrm{c}}$, a negative relationship was found, suggesting that attractiveness of alternatives have a lowering effect on normative commitment. Once again, an inspection of the VIF and tolerance levels revealed that multicollinearity among the independent variables was not a concern. The $\mathrm{R}^{2}$-value of 0.4001 revealed that about 40 per cent of the variance in normative commitment could be explained by the independent variables. 


\section{Interpretation and discussion}

The empirical results of the study are presented in Figure 2.

Figure 2: Summary of the hypotheses confirmed

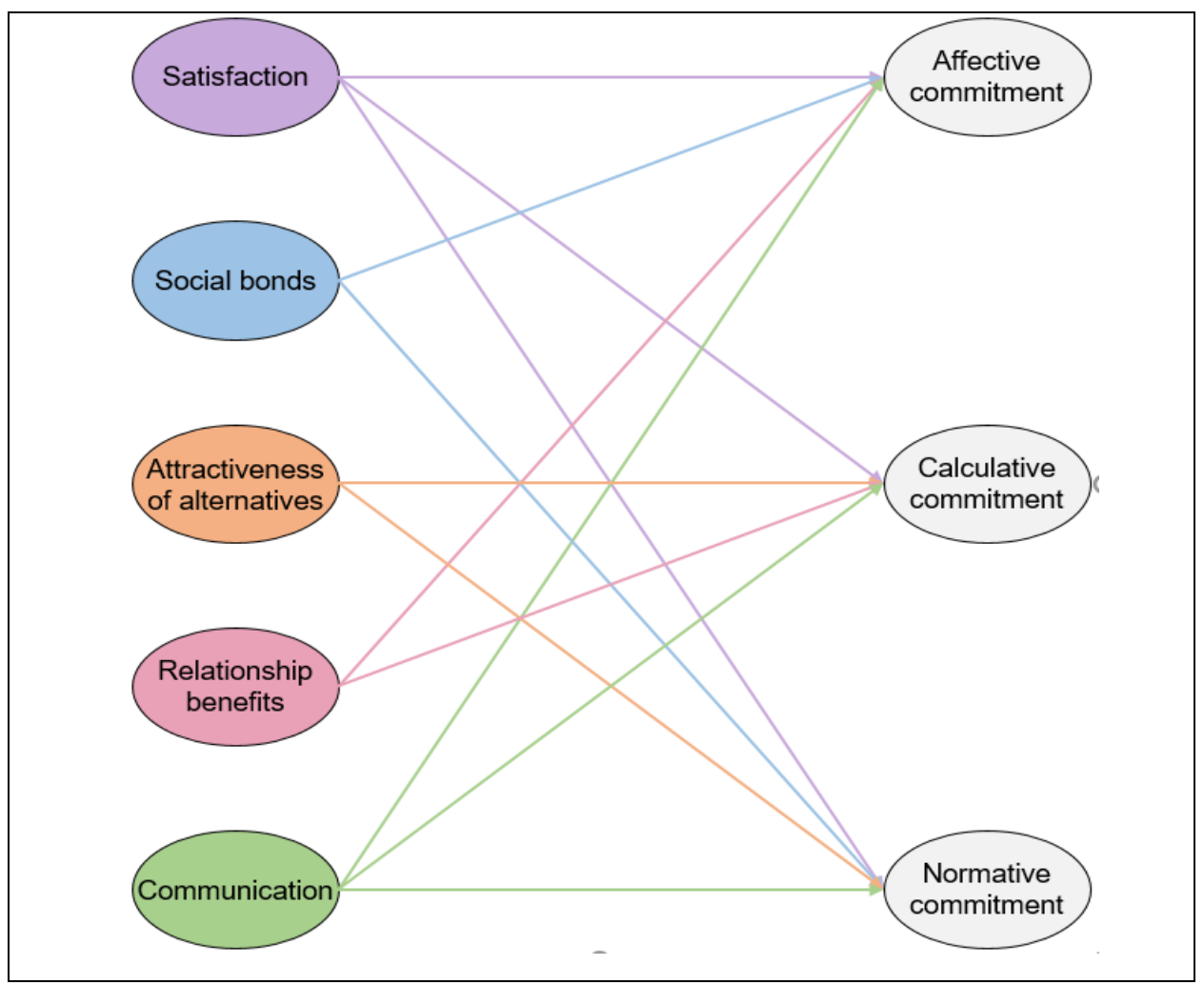

The first unexpected finding was that trust did not emerge as a separate construct in this study. Instead, some of the items used to measure trust was incorporated in the remaining antecedents. This result is in sharp contrast with the marketing literature that found trust to be an important antecedent of commitment. A reason for this deviation might be the context of the study, which focused on the South African hairdressing industry. It should be kept in mind that scales are often developed from an industrialised country perspective, and do not necessarily consider the unique characteristics of respondents in less-developed countries.

This study established a significant positive relationship between satisfaction and all three components of commitment. This outcome was to be expected, and supports the notion that hairdressers should focus on delivering satisfaction should they wish to successfully manage their clients' commitment (Cater \& Zabkar, 2009; Hennig-Thurau, 2004; Lee et al., 2007). The importance of social bonds when managing commitment was also confirmed in this study, especially in fostering affective and normative commitment. Once again, these findings concur with the literature (Fullerton, 2005; Ponder et al., 2016). The only exception was the expected positive effect that social bonds would have on calculative commitment, which did not realise. It is therefore 
apparent that social bonding, which is often characterised by a process of forming friendships, is not related to the rational and cognitive process of a customer's decision to commit towards a particular service provider.

The findings regarding attractiveness of alternatives when managing commitment were also foreseeable. It should be kept in mind that the items used to measure attractiveness of alternatives were formulated in such a manner that should alternatives become more attractive, it would erode the respondent's commitment towards their existing hairdresser. It was especially interesting to note that the attractiveness of alternative hairdressers did not influence the respondents' affective commitment, which confirms the notion that this component of commitment is of a more emotional nature. On the other hand, once alternative hairdressers become more attractive, it will have an influence on both a customer's calculative and normative commitment.

Significant positive relationships were confirmed between relationship benefits and both affective and calculative commitment, whilst no significant relationship was found between relationship benefits and normative commitment. Therefore, the more customers perceive that they receive benefits from their relationships with their hairdressers, the more committed they become. These findings are in line with the existing literature (Sweeney \& Webb, 2007; Theron et al., 2008; Dagger et al., 2011).

The fact that the study confirmed the important role of communication when managing commitment re-emphasises the critical role of communication in relationship marketing. Once again, this finding is in accordance with the marketing literature (Theron et al., 2008). Regardless of whether hairdressers attempt to manage affective, calculative or normative commitment, communication remains a corner stone of such efforts. By focusing on providing open, accurate and timely communication, hairdressers can go a long way in ensuring customer commitment.

In general, it should be remembered that all research efforts are always contextual, and that specific circumstances, industries and situations are reflected in the results. This study is no exception, as it is evident that the results reflect the unique character of the South African respondent.

\section{Recommendations}

To assist the hairdressing industry to interpret the results of this study, this section addresses some practical recommendations on each of the three types of commitment.

Given the unique and personal nature of hairdressing services, caution should be exercised when affective commitment is managed. The personal approach in this industry could therefore never be over-emphasised. It is thus important that hairdressers develop emotional attachments with their clients, which can be achieved by being sincere, and by creating friendships and a sense of belonging. In essence, customers 
should feel that they are part of a "family". It should also be remembered that different motivations exist for customers when they select a hairdresser. Often these motivations are derived from emotions, hence the term "affective" commitment.

Calculative commitment relies on cognitive and rational thought processes. Therefore, the hairdressing industry should realise that customers often make an informed decision (i.e. a non-emotional approach) when considering their future commitment. Given the competitiveness of the industry, alternatives are not only available, but customers are also aware of the availability of these alternative service providers. On the one hand it is the industry's responsibility to ensure that customers receive value for their money. On the other hand, switching barriers could be included to lock customers into relationships. However, offering value for money will always be the more desirable option. If a customer experiences proper value for money, the perception will be created that switching hairdressers will require considerable sacrifice, will be too costly and will disrupt the customer's life.

Normative commitment refers to customers feeling obligated to stay in a relationship with a particular service provider. According to the norm of reciprocity, customers will be committed to a firm or service provider once they see the investment that the firm or service provider has made in them as customers. Similarly, hairdressers should ensure that their clients recognise the investment that their hairdresser has made in the relationship. The concept of normative commitment also relates to the principle of guilt. If hairdressers invest in the relationship and offer social and emotional support, customers might feel guilty to terminate the relationship because the hairdresser has never failed them. The result is that the customer decides to stay with their hairdresser. This argument also places renewed emphasis on the importance of offering proper service quality.

\section{Limitations and future research}

The first limitation of the study is in terms of sampling, where the focus was on Generation $\mathrm{Y}$ only. Therefore, the generalisability of the results might be a concern. In addition, the study was conducted in a South African context, which once again raises questions as to whether the results of this study can be of value to hairdressers globally. Furthermore, since the study focused on the hairdressing industry, the results of the study can only be applied to this specific industry. One should therefore be cautious not to apply the results to a broader range of non-personal services. For example, the results are applicable to the hairdressing industry only, and not to the entire beauty industry.

The dimensionality of commitment from a personal care perspective deserves clarification. Once this clarification has been obtained, research should be conducted to identify unique sets of antecedents that are applicable to each of the three types of commitment. For example, the role of social bonding in managing affective and 
normative commitment is understandable; however, the question might be raised whether social bonding should at all be included in managing calculative commitment.

\section{Conclusion}

It is not often that the hairdressing industry is the focal point of research efforts. This study, however, investigated the management of calculative, affective and normative commitment from the perspective of the hairdressing industry. This research endeavour in itself provides valuable insights into an industry that is often not well understood.

As the hairdressing industry continues to grow, the level of competition will also escalate. It is thus important that hairdressers understand the instrumental role that relationship marketing plays in personal care service industries such as hairdressing. To tap into the benefits of the value of relationship marketing, hairdressers have to ensure that their customers remain committed to their services. This objective can only be achieved once hairdressers are attuned to the needs of their customers, and more importantly, if they focus on the management of each of the three types of commitment separately.

\section{Acknowledgement}

The invaluable contribution of Ms Enid-Marié Scholtz is hereby acknowledged, especially in assisting with the data collection.

\section{References}

Andersen, P.H. 2001. Relationship development and marketing communication: An integrative model. Journal of Business \& Industrial Marketing. 16(3):167-183.

Bansal, H.S., Irving, P.G. \& Taylor, S.F. 2004. A three-component model of customer to service providers. Journal of the Academy of Marketing Science. 32(3):234-250.

Beatty, S.E., Reynolds, K.E., Noble, S.M. \& Harrison, M.P. 2012. Understanding the relationships between commitment and voice: Hypotheses, empirical evidence, and directions for future research. Journal of Service Research. 15(3):296-315.

Bove, L.L. \& Robertson, N.L. 2005. Exploring the role of relationship variables in predicting customer voice to a service worker. Journal of Retailing and Consumer Services. 12(2):83-97.

Bricci, L., Fragata, A. \& Antunes, J. 2016. The effects of trust, commitment and satisfaction on customer loyalty in the distribution sector. Journal of Economics, Business and Management. 4(2):173-177.

Bügel, M.S., Buunk, A.P. \& Verhoef, P.C. 2010. A comparison of customer commitment in five sectors using the psychological investment model. Journal of Relationship Marketing. 9(1):2-29.

Bügel, M.S., Verhoef, P.C. \& Buunk, A.P. 2011. Customer intimacy and commitment to relationships with firms in five different sectors: Preliminary evidence. Journal of Retailing and Consumer Services. 18(4):247-258. 
By numbers: How big is the hair industry? 2017. [Online]. Available at: https://www.w24.co.za/Beauty/Hairstyles/by-numbers-how-big-is-the-hair-indus-try-20170927. Date accessed 20 February 2017.

Cater, B. 2006. A three-component model of commitment in professional service relationships on business-to-business markets. In 14th International Colloquium in Relationship Marketing. 1-17.

Cater, B. 2007. Trust and commitment in professional service marketing relationships in business-tobusiness markets. Managing Global Transitions. 5(4):371-390.

Cater, B. \& Zabkar, V. 2009. Antecedents and consequences of commitment in marketing research services: The client's perspective. Industrial Marketing Management. 38(7):785-797.

Chai, J., Deans, K. \& Biggemann, S. 2012. The influence of acculturation on consumer relational bonding in banking relationships. Journal of Strategic Marketing. 20(5):393-410.

Cohen, A. 2007. Commitment before and after: An evaluation and reconceptualization of organizational commitment. Human Resource Management Review. 17(3):336-354.

Curth, S., Uhrich, S. \& Benkenstein, M. 2014. How commitment to fellow customers affects the customerfirm relationship and customer citizenship behavior. Journal of Services Marketing. 28(2):147-158.

Dagger, T.S., David, M.E. \& Ng, S. 2011. Do relationship benefits and maintenance drive commitment and loyalty? Journal of Services Marketing. 25(4):273-281.

De Ruyter, K., Moorman, L. \& Lemmink, J. 2001. Antecedents of commitment and trust in customersupplier relationships in high technology markets. Industrial Marketing Management. 30(3):271286.

Fu, F.Q., Bolander, W. \& Jones, E. 2009. Managing the drivers of organisational commitment and salesperson effort: An application of Meyer and Allen's three-component model. Journal of Marketing Theory and Practice. 17(4):335-350.

Fullerton, G. 2003. When does commitment lead to loyalty? Journal of Service Research. 5(4):333-344.

Fullerton, G. 2005. The service quality-loyalty relationship in retail services: Does commitment matter? Journal of Retailing and Consumer Services. 12(2):99-111.

Fullerton, G. 2011. Creating advocates: The roles of satisfaction, trust and commitment. Journal of Retailing and Consumer Services. 18(1):92-100.

Global hair care market size 2012-2024. 2017. [Online]. Available at: https://www.statista.com/statistics/254608/global-hair-care-market-size/. Date accessed 20 February 2017.

Gruen, T.W., Summers, J.O. \& Acito, F. 2000. Relationship marketing activities, commitment, and membership behaviors in professional associations. Journal of Marketing. 64(3):34-49.

Gummerus, J., Von Koskull, C. \& Kowalkowski, C. 2017. Guest editorial: Relationship marketing - past, present and future. Journal of Services Marketing. 31(1):1-5.

Hair care in South Africa. 2017. [Online]. Available at: http://www.euromonitor.com/ hair-care-in-southafrica/report. Date accessed 21 February 2017.

Hennig-Thurau, T. 2004. Customer orientation of service employees: Its impact on customer satisfaction, commitment, and retention. International Journal of Service Industry Management. 15(5):460-478.

Hennig-Thurau, T., Gwinner, K.P. \& Gremler, D.D. 2002. Understanding relationship marketing outcomes: An integration of relational benefits and relationship quality. Journal of Service Research. 4(3):230-247.

Hocutt, M.A. 1998. Relationship dissolution model: Antecedents of relationship commitment and the likelihood of dissolving a relationship. International Journal of Service Industry Management. 
9(2):189-200.

Jones, T., Fox, G.L., Taylor, S.F. \& Fabrigar, L.R. 2010. Service customer commitment and response. Journal of Services Marketing. 24(1):16-28.

Kim, W. \& Ok, C. 2009. The effects of relational benefits on customers' perception of favorable inequity, affective commitment, and repurchase intention in full-service restaurants. Journal of Hospitality \& Tourism Research. 33(2):227-244.

Klein, H., Cooper, J., Molloy, J., \& Swanson, J. 2014. The assessment of commitment: Advantages of a unidimensional, target-free approach. Journal of Applied Psychology, 99(2):222-238.

Lee, K.Y., Huang, H.L. \& Hsu, Y.C. 2007. Trust, satisfaction and commitment - On loyalty to international retail service brands. Asia Pacific Management Review. 12(3):161-169.

Meyer, J.P. \& Allen, N.J. 1991. A three-component conceptualization of organizational commitment. Human Resource Management Review. 1(1):61-89.

Meyer, J.P., Stanley, D.J., Herscovitch, L. \& Topolnytsky, L. 2002. Affective, continuance, and normative commitment to the organization: A meta-analysis of antecedents, correlates, and consequences. Journal of Vocational Behavior. 61(1):20-52.

Moorman, C., Zaltman, G. \& Deshpande, R. 1992. Relationships between providers and users of market research: The dynamics of trust within and between organizations. Journal of Marketing Research. 29(3):314-328.

Nusair, K., Parsa, H.G. \& Cobanoglu, C. 2011. Building a model of commitment for Generation Y: An empirical study on e-travel retailers. Tourism Management. 32(4):833-843.

Parsa, S., \& Sadeghi, T. 2015. Effect of relationship marketing on word of mouth in life insurance with the approach of trust and commitment: Case study of Karafarin insurance agents in Mashhad. International Journal of Management, Accounting \& Economics. 2(10):1244-1260.

Paulssen, M. \& Roulet, R. 2017. Social bonding as a determinant of share of wallet and cross-buying behaviour in B2B relationships. European Journal of Marketing. 51(5/6):1011-1028.

Ponder, N., Holloway, B.B. \& Hansen, J.D. 2016. The mediating effects of customers' intimacy perceptions on the trust-commitment relationship. Journal of Services Marketing. 30(1):75-87.

Sharma, N. \& Patterson, P.G. 2000. Switching costs, alternative attractiveness and experience as moderators of relationship commitment in professional, consumer services. International Journal of Service Industry Management. 11(5):470-490.

Shemwell, D.J., Yavas, U. \& Bilgin, Z. 1998. Customer-service provider relationships: An empirical test of a model of service quality, satisfaction and relationship-oriented outcomes. International Journal of Service Industry Management. 9(2):155-168.

Sohaib, M., Rehman, U.A.M. \& Akram, U. 2016. Underlying effect of customer satisfaction on repurchase intentions: Mediating role of trust and commitment. European Journal of Business and Management. 8(10):105-115.

Standifer, R.L., Evans, K.R. \& Dong, B. 2010. The influence of spirituality on buyer perception within business-to-business marketing relationships: A cross-cultural exploration and comparison. Journal of Relationship Marketing. 9(3):132-160.

Statista. 2015. Value of the beauty and personal care market worldwide in 2015, by country (in million U.S. dollars). [Online], Available: https://www.statista.com/ statistics/562081/global-beauty-andpersonal-care-market-value-by-country/ [2017, February 13].

Sweeney, J.C. \& Webb, D.A. 2007. How functional, psychological, and social relationship benefits influence individual and firm commitment to the relationship. Journal of Business \& Industrial 
Marketing. 22(7):474-488.

Ter Hoeven, C.L. \& Verhoeven, J.W.M. 2013. "Sharing is caring": Corporate social responsibility awareness explaining the relationship of information flow with affective commitment. Corporate Communications: An International Journal. 18(2):264-279.

Theron, E. \& Terblanche, N.S. 2010. Dimensions of relationship marketing in business-to-business financial services. International Journal of Market Research. 52(3):383-402.

Theron, E., Terblanche, N.S. \& Boshoff, C. 2008. The antecedents of relationship commitment in the management of relationships in business-to-business (B2B) financial services. Journal of Marketing Management. 24(9/10):997-1010.

Tsunogaya, N, Sugahara, S. \& Chand, P. 2017. The impact of social influence pressures, commitment, and personality on judgments by auditors: Evidence from Japan. Journal of International Accounting Research. 16(3):17-34.

Van Vuuren, T., Roberts-Lombard, M. \& Van Tonder, E. 2012. Customer satisfaction, trust and commitment as predictors of customer loyalty within an optometric practice environment. Southern African Business Review. 16(3):81-96.

Wang, E.S.T. 2014. The effects of relationship bonds on emotional exhaustion and turnover intentions in frontline employees. Journal of Services Marketing. 28(4):319-330.

Watson, S. 2012. Consumer responses to service situations: Tests for main and interaction effects. Journal of Retailing and Consumer Services. 19(3):287-296.

Wetzels, M., De Ruyter, K. \& Van Birgelen, M. 1998. Marketing service relationships: The role of commitment. Journal of Business \& Industrial Marketing. 13(4/5):406-423.

Wu, W.Y., Chiag, C.Y., Wu, Y.J. \& Tu, H.J. 2004. The influencing factors of commitment and business integration on supply chain management. Industrial Management \& Data Systems. 104(4):322333.

Yim, C.K.B., Chan, K.W. \& Hung, K. 2007. Multiple reference effects in service evaluations: Roles of alternative attractiveness and self-image congruity. Journal of Retailing. 83(1):147-157.

Zhang, J., Watson, G., Palmatier, R. \& Dant, R. 2016. Dynamic relationship marketing. Journal of Marketing, 80(5):53-59. 